\title{
VARIABILITAS GENETIK DAN HERITABILITAS KARAKTER MORFOLOGIS BEBERAPA GENOTIPE KENTANG
}

\section{GENETIC VARIABILITY AND MORPHOLOGIC HERITABILITY CHARACTERS OF SOME GENOTYPES OF POTATO}

\author{
Ventje Pangemanan, D.S. Runtunuwu, dan J. Pongoh*) \\ *) Jurusan Budidaya Pertanian Fakultas Pertanian Unsrat \\ e-mail: pangemananventje@ymail.com
}

\begin{abstract}
This study aimed to determine the genetic variability and heritability of morphological characters of some genotypes of potato at the Seed Station in Linelean Village, Modoinding of South Minahasa Regency. The results showed that, the relatively narrow range of genotypes variance for all the characters observed. The coefficient of variance genotypes for plant height, at 14, 42 and 56 DAP (Days After Planting) was relatively narrow, whereas at 7, 21, 28, 35 and 42 DAP relatively wide. For the character of the number of leaves at 7 and 14 DAP are wide and at 21, 28, 35, 42 and 49 DAP relatively narrow. For the character of leaf area at 7 and 14 DAP were wide and at 21, 28, 35, 42 and 49 DAP relatively narrow. For the character of the number of harvest tubers per plant and weight per tuber harvest were wide. Wide sense heritability were high for all the characters observed, except for plant height at 7 and 56 DAP were classified as moderate.
\end{abstract}

Keywords: genotype variance, coefficient variance of genotype and heritability

\begin{abstract}
ABSTRAK
Penelitian ini bertujuan untuk mengetahui variabilitas genetik dan heritabilitas karakter morfologis beberapa genotipe kentang di Balai Benih Desa Linelean Modoinding Kabupaten Minahasa Selatan. Hasil penelitian menunjukkan bahwa ragam genotipe tergolong sempit untuk semua karakter yang diamati. Koefisien ragam genotipe untuk karakter tinggi tanaman, pada 14, 42 dan 56 HST (Hari Setelah Tanam) tergolong sempit, sedangkan pada 7, 21, 28, 35 dan 42 HST tergolong luas. Untuk karakter jumlah daun pada 7 dan 14 HST tergolong luas dan pada 21, 28, 35, 42 dan 49 HST tergolong sempit. Untuk karakter luas daun pada 7 dan 14 HST tergolong luas dan pada 21, 28, 35, 42 dan 49 HST tergolong sempit. Untuk karakter jumlah umbi panen per tanaman dan berat per umbi panen tergolong luas. Heritabilitas arti luas semua karakter tergolong tinggi, kecuali untuk karakter tinggi tanaman pada 7 dan 56 HST yang tergolong sedang.

Kata kunci: ragam genotipe, koefisien ragam genotipe dan heritabilitas
\end{abstract}

Eugenia Volume 19 No. 2 Agustus 2013 


\section{PENDAHULUAN}

Produktivitas kentang di Indonesia tahun 2012 yaitu 16,58 ton/ha. Untuk Sulawesi Utara, produksi tahun 2012 yaitu 14,52 ton/ha (BPS, 2014). Ini masih jauh dibandingkan dengan produksi dari negara-negara maju seperti Eropa 25,50 ton/ha (Pusat Data dan Informasi Pertanian, 2013), Australia 29,00 ton/ha, Jepang 37,00 ton/ha dan Amerika Serikat 37,00 ton/ha (Samadi, 2007). Masih rendahnya produktivitas kentang di Indonesia ini disebabkan oleh berbagai faktor antara lain: 1) Teknologi budidaya yang diterapkan petani belum maju karena adopsi teknologi oleh petani masih lambat, 2) Pengaruh lingkungan tropis yang menyebabkan banyaknya serangan hama dan penyakit, 3) Penggunaan/adopsi benih unggul yang masih terbatas dan 4) Kurangnya produksi benih unggul serta kurangnya penangkar benih unggul. Benih berkualitas yang dapat disediakan oleh penangkar dan balai benih kentang baru sekitar $5 \%$ dari total kebutuhan benih kentang nasional (Anonimous, 2011a).

Peningkatan produktivitas tanaman dapat dilakukan melalui manipulasi atau pengaturan lingkungan tumbuh dan memperbaiki potensi genetik tanaman. Perbaikan potensi genetik tanaman hanya dapat dilakukan melalui pemuliaan tanaman tersebut. Penelitian tentang variabilitas genetik pada tanaman kentang di Indonesia belum banyak dilakukan. Kentang bukan tanaman asli Indonesia tapi introduksi dari luar negeri, karena itu variabilitas genetik plasmanutfah kentang di Indonesia terbatas. Perbanyakan kentang secara vegetatif juga membatasi terciptanya variabilitas genetik baru. Sempitnya latar belakang genetik akan menyebabkan stagnasi dalam program pemuliaan. Kentang tergolong tetraploid $(2 n=2 x=48)$. Persilangan antar tetraploid akan menghasilkan variabilitas genetik yang tinggi untuk banyak karakter (Uijtewall, 1987 dalam Maharijaya, Mahmud dan Prawiro, 2008) sehingga diperlukan populasi yang lebih besar dibandingkan dengan diploid. Sebagai akibatnya kegiatan seleksi awal (screening) penting untuk dilakukan untuk mengurangi jumlah klon yang harus diseleksi di lapangan. Keadaan ini menyebabkan penelitian tentang variabilitas genetik kentang membutuhkan waktu lebih lama dan biaya lebih besar. Tapi bagaimanapun variabilitas genetik merupakan bahan baku pemuliaan tanaman, tanpa itu tak akan ada perbaikan potensi genetik tanaman.

Langka awal dalam program pemuliaan kentang yaitu evaluasi terhadap material pemuliaan (genotipe/klon kentang). Program pemuliaan kentang dapat melalui seleksi, hibridisasi dan mutasi. Seleksi pada tanaman agar supaya efektif, perlu diketahui beberapa parameter genetik, seperti: variabilitas genetik dan heritabilitas karakter-karakter yang akan dijadikan kriteria seleksi. Variabilitas genetik yang luas merupakan salah satu syarat efektifnya program seleksi. Seleksi untuk karakter yang diinginkan akan lebih berarti jika karakter tersebut mudah diwariskan. Mudah tidaknya suatu karakter diwariskan dapat diketahui dari besarnya nilai heritabilitas karakter tersebut. Seleksi pada tanaman kentang bertujuan untuk mendapatkan genotipe unggul untuk keperluan budidaya dan untuk mendapatkan calon tetua unggul untuk keperluan hibridisasi kentang. Seberapa besar kemungkinan suatu karakter diwariskan, diukur dengan nilai heritabilitas karakter tersebut. Karena itu kajian tentang variabilitas genetik dan heritabilitas karakter morfologis beberapa genotipe kentang perlu dilakukan.

Penelitian ini bertujuan untuk mengetahui variabilitas genetik dan heritabilitas arti luas dari karakter morfologis beberapa genotipe kentang. Diharapkan lewat penelitian ini dapat memberikan informasi bagi pemulia dalam menyusun program pemuliaan untuk merakit genotipe unggul baru tanaman kentang.

\section{METODE PENELITIAN}

Penelitian ini dilakukan di Balai Benih Dinas Pertanian dan Peternakan Provinsi Sulawesi Utara Desa Linelean Kecamatan Modoinding Kabupaten Minahasa Selatan, dari Juni sampai Desember 2010. Bahan yang digunakan dalam penelitian ini yaitu: umbi bibit kentang $G_{1}$ dari Bogor, $G_{3}$ dari Dieng dan $G_{x}$ dari Modoinding; pupuk kandang ayam, pupuk Urea, $\mathrm{KCl}$ dan SP-36; pestisida Balistic 50SC, Demolish 18EC, Furadan 
3GR, Phytoklor 82S dan Supremo 480SL. Alat yang digunakan yaitu: cangkul, sekop, meteran, timbangan analitik, timbangan digital, timbangan gantung, hand sprayer, karung plastik, tali plastik dan alat tulis-menulis.

Model penelitian ini yaitu penelitian eksperimen yang diatur dalam Rancangan Acak Kelompok dengan tiga perlakuan diulang sebanyak tiga kali. Perlakuan yaitu tiga genotipe kentang Granola. Perlakuan A ( $G_{1}$ Bogor), perlakuan B ( $\mathrm{G}_{3}$ Dieng) dan perlakuan $\mathrm{C}\left(\mathrm{G}_{\times}\right.$Modoinding).

Variabel yang diamati yaitu: tinggi tanaman, jumlah daun, luas daun, jumlah umbi panen per tanaman dan berat per umbi panen. Pengamatan dilakukan setiap minggu sejak umur 7 HST (hari setelah tanam) hingga 56 HST.

Data dianalisis dengan Analisis Ragam. Lewat analisis tersebut diperoleh nilai M1 (Kuadrat Tengah galat) dan M2 (Kuadrat Tengah perlakuan/genotipe), dengan demikian ragam genotipe $\left(\sigma^{2} g\right)$, ragam fenotipe $\left(\sigma^{2} p\right)$, simpangan baku ragam genotipe $\left(\sigma \sigma^{2} \mathrm{~g}\right)$, koefisien ragam genotipe (CVG), koefisien ragam fenotipe (CVP) dan heritabilitas arti luas dapat dihitung dengan rumus seperti berikut ini:

Ragam genotipe: $\sigma^{2} g=\frac{M 2-M 1}{r} \quad($ Singh dan Chaudhary, 1979).

Ragam fenotipe: $\sigma^{2} p=\frac{M 2}{r} \quad$ (Singh dan Chaudhary, 1979).

Simpangan baku ragam genotipe:

$\sigma \sigma^{2} g=\sqrt{ } \frac{2}{r^{2}} \frac{K_{\text {Tgenotipe }}^{2}}{\text { dbgenotipe }+2}+\frac{\text { KTgalat }^{2}}{\text { dbgalat }+2}$ ?

(Anderson dan Burton (1952) dalam Wahdah et al, 1996).

Koefisien ragam genotipe:

CVG $=\frac{\sqrt{\sigma^{2} g}}{\bar{x}} \times 100 \%$ (Burton, 1952).

Koefisien ragam fenotipe:

CVP $=\frac{\sqrt{\sigma^{2} p}}{\bar{x}} \times 100 \%$ (Burton, 1952).
Heritabilitas arti luas:

$\mathrm{H}^{2}=\frac{\sigma^{2} g}{\sigma^{2} p} \times 100 \%$ (Zuzuki et al, 1989).

Variabilitas genetik dinyatakan dengan nilai ragam genotipe dan koefisien ragam genotipe. Jika ragam genotipe nilainya lebih besar dari $2 x$ nilai simpangan baku ragam genotipe maka variabilitas genetik dari suatu karakter dikategorikan luas, jika sama atau lebih kecil dari $2 x$ simpangan baku ragam genotipe dikategorikan sempit. Jika koefisien ragam genotipe nilainya lebih besar dari $50 \%$, variabilitas genetik suatu karakter dikategorikan luas dan jika lebih kecil $50 \%$, dikategorikan sempit. Untuk heritabilitas arti luas, jika nilainya $<20 \%$ tergolong rendah, $20-50 \%$ tergolong sedang dan $>50 \%$ tergolong tinggi.

\section{HASIL DAN PEMBAHASAN}

Hasil penelitian seperti pada Tabel 1 sampai Tabel 5 menunjukkan bahwa karakter tinggi tanaman ragam genotipenya $\left(\sigma^{2} g\right)$ terletak pada kisaran $0,077-2,813$ dan tergolong sempit untuk semua umur. Terendah pada 7 HST dan tertinggi pada 49 HST. Koefisien ragam genotipe (CVG) terletak pada kisaran $0,65-4,10 \%$. Terendah pada 56 HST dan tertinggi pada 28 HST. Pada umur $7,21,28,35$ dan 49 HST tergolong luas. Pada umur 14, 42 dan 56 HST tergolong sempit. Untuk nilai duga heritabilitas arti luas terletak pada kisaran angka $40-92,14 \%$. Terendah pada 56 HST dan tertinggi pada 49 HST. Tergolong tinggi untuk 14, 21, 28, 35, 42 dan 49 HST. Tergolong sedang untuk 7 dan 56 HST.

\section{Jumlah Daun}

Karakter jumlah daun, ragam genotipe $\left(\sigma^{2} g\right)$ antara 1,669 - 11,399. Terendah pada 7 HST dan tertinggi pada 35 HST. Tergolong sempit untuk semua umur pengamatan. Koefisien ragam genotipe (CVG) antara 3,68 - 21,71\%. Terendah pada 42 HST dan tertinggi pada 14 HST. Tergolong luas untuk 7 dan 14 HST. Tergolong sempit untuk 21, 28, 35, 42 dan 49 HST. Nilai duga heritabilitas arti luas terletak antara 72,12 $98,21 \%$. Tergolong tinggi untuk semua umur pengamatan. 


\section{Luas Daun}

Untuk karakter luas daun, ragam genotipe $\left(\sigma^{2} g\right)$ antara 6,269 - 299,371. Terendah pada 7 HST dan tertinggi pada 35 HST. Tergolong sempit untuk semua umur pengamatan. Koefisien ragam genotipe (CVG), antara 1,26-21,70\%. Terendah pada 49 HST dan tertinggi pada 14 HST. Tergolong luas pada 7 HST dan 14 HST. Tergolong sempit untuk 21, 28, 35, 42 dan 49 HST. Untuk nilai duga heritabilitas arti luas, terletak antara 71,12 $98,19 \%$. Terendah pada 49 HST dan tertinggi pada 14 HST. Tergolong tinggi untuk semua umur pengamatan.

\section{Jumlah Umbi Panen}

Untuk karakter jumlah umbi panen per tanaman, ragam genotipe $\left(\sigma^{2} g\right)$ sebesar 7,342 dan tergolong sempit. Koefisien ragam genotipe sebesar $29,07 \%$ dan tergolong luas. Nilai duga heritabilitas arti luas sebesar $87,38 \%$ dan tergolong tinggi.

\section{Berat Umbi Panen}

Karakter berat per umbi panen, ragam genotipe $\left(\sigma^{2} \mathrm{~g}\right)$ nilainya 126,59 dan tergolong sempit. Koefisien ragam genotipe (CVG) sebesar $19,10 \%$ dan tergolong luas. Nilai duga heritabilitas arti luas sebesar $96,89 \%$ dan tergolong tinggi.

Kalau menggunakan parameter ragam genotipe $\left(\sigma^{2} g\right)$, semua karakter tergolong berkeragaman genetik sempit. Secara teori memang tanaman hasil perbanyakan vegetatif akan sama seperti tetuanya atau tidak ada keragaman genetik kecuali terjadi mutasi. Kalau menggunakan parameter koefisien ragam genotipe (CVG), maka terdapat juga karakter yang berkeragaman genetik luas. Kentang hasil perbanyakan secara kultur jaringan dimana melibatkan penggunaan bahanbahan kimia, bisa saja menyebabkan terjadinya mutasi dan selanjutnya tercipta keragaman somaklonal (Larkin dan Scowcroft, 1981). Adanya perbedaan kriteria keragaman genetik dari suatu karakter jika menggunakan parameter ragam genotipe $\left(\sigma^{2} g\right)$ dan koefisien ragam genotipe (CVG) disebabkan oleh cara penggolongan yang berbeda. Penggolongan/ kriteria luas sempitnya ragam genotipe $\left(\sigma^{2} g\right)$ yang berdasarkan kriteria Singh dan Chaudhary (1979) tidak membedakan antara tanaman yang diperbanyak secara generatif dan yang diperbanyak secara vegetatif. Padahal tanaman yang diperbanyak secara generatif pasti keragaman genetiknya lebih luas dari yang diperbanyak secara vegetatif. Dalam pemuliaan tanaman, parameter genetik yang digunakan sebagai syarat agar seleksi efektif tidak cukup hanya satu saja, misalnya variabilitas genetik atau heritabilitas saja. Variabilitas genetik yang luas belum menjamin keefektifan program seleksi terhadap genotipe-genotipe yang diseleksi. Keefektifan seleksi akan semakin tinggi jika karakter yang digunakan sebagai kriteria seleksi mempunyai variabilitas genetik yang luas, heritabilitas yang tinggi dan kemajuan genetik (Genetic Advanced in persen/GA\%) yang tinggi (Mondal 2003 in Ara et al, 2009). Karakter-karakter dengan nilai duga heritabilitas yang tinggi, dalam pemuliaan tanaman berarti bahwa kalau karakterkarakter tersebut dijadikan kriteria untuk seleksi maka pada generasi berikutnya maka karakterkarakter tersebut akan diwariskan sebagaimana pada generasi sebelumnya. Lebih jelasnya misalnya kalau karakter jumlah umbi yang tinggi dipilih untuk jadi kriteria seleksi maka pada generasi berikutnya juga akan memberikan jumlah umbi yang tinggi. Karakter yang nilai heritabilitas tinggi menunjukkan bahwa ragam genotipe lebih berperan dari ragam lingkungan. Apabila ragam genotipe lebih berperan maka seleksi terhadap sifat tersebut akan memberikan kemajuan genetik yang berarti. Seleksi terhadap karakter yang nilai heritabilitasnya tinggi dapat dilakukan pada generasi awal dan seleksi pada karakter yang nilai heritabilitasnya rendah dilakukan pada generasi lanjut (Fehr, 1987). Berdasarkan hasil penelitian ini, di mana karakter jumlah umbi panen per tanaman dan berat per umbi panen mempunyai variabilitas genetik luas dan heritabilitas yang tinggi. Dengan demikian maka karakter jumlah umbi panen per tanaman dan berat per umbi panen merupakan karakter penting untuk seleksi dalam rangka perbaikan hasil produksi tanaman kentang. 
Tabel 1. Variabilitas Genetik dan Heritabilitas Karakter Tinggi Tanaman

(Table 1. Genetic Variability and Character Heritability of Plant Height)

\begin{tabular}{ccccccc}
\hline \multicolumn{2}{c}{ Umur } & \multicolumn{3}{c}{ Variabilitas Genetik } & \multicolumn{3}{c}{ Heritabilitas } \\
$($ HST $)$ & $\sigma^{2} \mathrm{~g}$ & Kriteria & CVG $(\%)$ & Kriteria & $\mathrm{H}^{2}(\%)$ & Kriteria \\
\hline 7 & 0,077 & sempit & 2,83 & luas & 42,78 & sedang \\
14 & 0,128 & sempit & 0,93 & sempit & 79,01 & tinggi \\
21 & 0,71 & sempit & 3,39 & luas & 66,98 & tinggi \\
28 & 2,14 & sempit & 4,10 & luas & 89,92 & tinggi \\
35 & 2,14 & sempit & 3,25 & luas & 78,68 & tinggi \\
42 & 0,35 & sempit & 0,90 & sempit & 68,63 & tinggi \\
49 & 2,813 & sempit & 2,15 & luas & 92,14 & tinggi \\
56 & 0,175 & sempit & 0,65 & sempit & 40,00 & sedang \\
\hline
\end{tabular}

Keterangan: HST = Hari Setelah Tanam, $\sigma^{2} g=$ ragam genotipe,

$C V G=$ koefisien ragam genotipe dan $\mathrm{H}^{2}=$ heritabilitas arti luas

Tabel 2. Variabilitas Genetik dan Heritabilitas Karakter Jumlah Daun

(Table 2. Genetic Variability and Character Heritability of Number of Leaves)

\begin{tabular}{|c|c|c|c|c|c|c|}
\hline \multicolumn{2}{|c|}{ Umur } & \multicolumn{2}{|c|}{ Variabilitas Genetik } & \multicolumn{3}{|c|}{ Heritabilitas } \\
\hline (HST) & $\sigma^{2} g$ & Kriteria & CVG $(\%)$ & Kriteria & $H^{2}(\%)$ & Kriteria \\
\hline 7 & 1,669 & sempit & 18,20 & luas & 91,20 & tinggi \\
\hline 14 & 6,646 & sempit & 21,71 & luas & 98,21 & tinggi \\
\hline 21 & 1,937 & sempit & 5,89 & sempit & 72,12 & tinggi \\
\hline 28 & 7,551 & sempit & 6,69 & sempit & 91,63 & tinggi \\
\hline 35 & 11,399 & sempit & 6,79 & sempit & 95,80 & tinggi \\
\hline 42 & 4,336 & sempit & 3,68 & sempit & 91,73 & tinggi \\
\hline 49 & 9,481 & sempit & 5,44 & sempit & 71,12 & tinggi \\
\hline
\end{tabular}

Tabel 3. Variabilitas Genetik dan Heritabilitas Karakter Luas Daun

(Table 3. Genetic Variability and Character Heritability of Leaves Area)

\begin{tabular}{|c|c|c|c|c|c|c|}
\hline \multicolumn{2}{|r|}{ Umur } & \multicolumn{2}{|c|}{ Variabilitas Genetik } & \multicolumn{2}{|c|}{ Heritabilitas } & \multirow[b]{2}{*}{ Kriteria } \\
\hline (HS & $\sigma^{2} g$ & Kriteria & CVG $(\%)$ & Kriteria & $\mathrm{H}^{2}(\%)$ & \\
\hline 7 & 6,269 & sempit & 18,20 & luas & 91,17 & tinggi \\
\hline 14 & 30,41 & sempit & 21,70 & luas & 98,19 & tinggi \\
\hline 21 & 7,615 & sempit & 5,88 & sempit & 72,18 & tinggi \\
\hline 28 & 53,67 & sempit & 6,69 & sempit & 91,62 & tinggi \\
\hline 35 & 299,371 & sempit & 6,79 & sempit & 95,79 & tinggi \\
\hline 42 & 279,159 & sempit & 3,68 & sempit & 91,74 & tinggi \\
\hline 49 & 74,826 & sempit & 1,26 & sempit & 71,12 & tinggi \\
\hline
\end{tabular}


Tabel 4. Variabilitas Genetik dan Heritabilitas Karakter Jumlah Umbi Panen per Tanaman

(Table 4. Genetic Variability and Character Heritability of Number of Harvest Tuber per Plant)

\begin{tabular}{cccccc}
\hline & \multicolumn{2}{c}{ Variabilitas Genetik } & \multicolumn{2}{c}{ Heritabilitas } \\
$\sigma^{2} g$ & Kriteria & CVG $(\%)$ & Kriteria & $\mathrm{H}^{2}(\%)$ & Kriteria \\
\hline 7,342 & sempit & 29,07 & luas & 87,38 & tinggi \\
\hline
\end{tabular}

Tabel 5. Variabilitas Genetik dan Heritabilitas Karakter Berat per Umbi Panen

(Table 5. Genetic Variability and Character Heritability of Weight per Harvest Tuber)

\begin{tabular}{cccccc}
\hline & \multicolumn{3}{c}{ Variabilitas Genetik } & \multicolumn{2}{c}{ Heritabilitas } \\
$\sigma^{2} g$ & Kriteria & CVG $(\%)$ & Kriteria & $H^{2}(\%)$ & Kriteria \\
\hline 126,59 & sempit & 19,10 & luas & 96,89 & tinggi \\
& & & & & \\
\hline
\end{tabular}

\section{KESIMPULAN DAN SARAN}

\section{Kesimpulan}

Variabilitas genetik dari semua karakter yang diteliti jika menggunakan parameter ragam genotipe $\left(\sigma^{2} g\right)$ tergolong sempit. Jika menggunakan parameter koefisien ragam genotipe (CVG) karakter tinggi tanaman sebagian besar tergolong luas, karakter jumlah daun dan luas daun sebagian besar tergolong sempit, karakter jumlah umbi panen per tanaman dan karakter berat per umbi panen tergolong luas.

Nilai duga heritabilitas arti luas untuk semua karakter yang diteliti tergolong tinggi, kecuali karakter tinggi tanaman 7 HST dan 56 HST yang tergolong sedang.

Karakter jumlah umbi panen per tanaman dan berat per umbi panen memiliki koefisien ragam genotipe luas dan nilai duga heritabilitas arti luas yang tinggi.

\section{Saran}

Karakter jumlah umbi panen per tanaman dan berat per umbi panen, dapat dijadikan kriteria seleksi dalam rangka perbaikan kuantitas dan kualitas produksi tanaman kentang yang diteliti.

\section{DAFTAR PUSTAKA}

Anonimous.

2011a.

Kentang.

http://www.unhas.ac.id/content/sulselsasar-pasok-bibit-kentang-nasional, diakses 10 Februari 2011.

Ara, T., A. Haydar., M. A. Islam, M.A.S. Azad and E.H. Khokan. 2009. Path Analysis in Potato. Department of Botany. University of Rajshahi, Rajshahi. http://ggfjournals.com/assets/uploads/2023.pdf, diakses 2 Mei 2014.

Badan Pusat Statistik. 2014. Statistik Indonesia. Badan Pusat Statistik. Jakarta

Burton, G. W. 1952. Quantitative Inheritance in Pearl Millet (Pennisetum glaucum). Agron. J. 43: $409-457$.

Burton, G.W. and E. H. DeVane. 1953. Estimating Heritability in Tall Fescue (Festuca arundinacea) from Replicated Clonal Material. Agron. J. 45: $478-481$

Fehr, W. R. 1987. Principle of Cultivar Development. Macmillan. New York. London.

Larkin, P. J. and W. R. Scowcroft. 1981. Somaclonal Variation-a Novel Source of Variability From Cell Culture for Plant Improvement. Theor \& Appl Gen. 60: 197 - 214. 
Maharijaya, A., M. Mahmud dan A. Prawiro. 2008.

Uji Ketahanan in vitro Klon-klon Kentang Hasil Persilangan Kentang Kultivar Atlantik dan Granola Terhadap Penyakit Layu Bakteri (Ralstonia solanacearum) dan Busuk Lunak (Erwinia carotovora). Bul. Agron. (36)(2): 133 - 138.

Pusat Data Dan Informasi Pertanian. 2013. Buletin Konsumsi Pangan. Vol. 4 No. 1. Thn 2013. http://pusdatin.setjen.pertanian.go.id/, diakses 18 Maret 2014.

Samadi. 2007. Kentang dan Analisis Usahatani. Kanisius. Yogyakarta.
Singh, R.K. and B.D. Chaudhary. 1979. Biometrical Method in Quantitative Genetic Analysis. Kalyani Pub. Ludhiana. New Delhi.

Suzuki, D.T., A. J. F. Griffiths., J. H. Miller and R. C. Lewontin. 1989. An Introduction to Genetic Analysis. 4th Ed. W. H. Freeman And Company. New York.

Wahdah, R., A. Baihaki, R. Setiamihardja dan G. Suryatmana. 1996. Variabilitas dan Heritabilitas Laju Akumulasi Bahan Kering Pada Biji Kedelai. Zuriat 7 (2): 92 - 97. 